\title{
Prototipe Aplikasi Pembelajaran Bagi Anak Berkebutuhan Khusus dengan Menerapkan Pendekatan Gamification
}

\author{
${ }^{1}$ Tri Sagirani, ${ }^{2}$ Nunuk Wahyuningtyas, ${ }^{3}$ Sri Hariani Eko Wulandari, \\ ${ }^{4}$ Wawan W. Efendi \\ 1,2,3,4 Program Studi Sistem Informasi, Fakultas Teknologi \& Informatika, Universitas Dinamika, \\ Jl. Raya Kedung Baruk 98 Surabaya, Indonesia \\ e-mail: tris@dinamika.ac.id
}

\begin{abstract}
Abstrak
Mewabahnya Corona Virus Disease 2019 (COVID-19) menuntut seluruh masyarakat untuk berubah, tidak terkecuali di bidang pendidikan. Pemerintah mengeluarkan kebijakan belajar di rumah untuk mengurangi penyebaran virus. Bagi siswa pada umumnya belajar di rumah relatif tidak menimbulkan hambatan berarti. Sedangkan bagi siswa berkebutuhan khusus membutuhkan metode belajar yang mampu membuat mereka berpikir bahwa mereka bersekolah karena ada jadwal pelajaran yang tersaji seperti di sekolah serta konten materi yang menarik minat belajar agar mereka bisa berkonsentrasi menerima materi. Semua proses belajar tersebut haruslah memudahkan orang tua untuk mendampingi mereka belajar. Penelitian ini memberikan alternatif solusi media pembelajaran berupa aplikasi berbasis android dengan menggunakan pendekatan gamification yang memanfaatkan elemen karakter, tantangan, interaktif, cerita, umpan balik dan kebebasan untuk gagal. Aplikasi ini menghadirkan kemudahan untuk orang tua dalam menyusun jadwal harian anak, memilihkan aktiftas yang cocok untuk anak dan memberikan ruang untuk kolaborasi orang tua dan anak. Bagi anak, aplikasi ini dapat membantu untuk tetap bersemangat dalam belajar seperti di sekolah dengan cara yang lebih menyenangkan. Aplikasi diuji coba terbatas menggunakan System Usability Scale (SUS) sebagai tolok ukur persepsi kegunaan system, dengan hasil 85,3 yang artinya memiliki grade scale "B" dengan Adjective Rating "Excellent".
\end{abstract}

Kata kunci: gamification; anak berkebutuhan khusus; media pembelajaran.

\begin{abstract}
Outbreaks of Corona Virus Disease (COVID-19) require the entire community to change, including education. The government issued a home study policy to reduce the spread of the virus. For students, studying at home relatively does not pose significant obstacles. Whereas for disabilities students, they need learning methods which able make them think that they are studying at school because there are scheduled lessons such as at school and material content that interests them in learning. So, they can concentrate on receiving the material. All learning processes must make it easier for parents to assist them in learning. This study provides a solution through learning media for disabilities in the form of an android-based application using a gamification approach that utilizes elements of character, challenges, interactive, stories, feedback and freedom to fail. This application presents convenience for parents in creating a child's daily schedule, selecting activities that are suitable for disabilities students and providing space for parent and child collaboration. For children, this application can help to stay enthusiastic in learning like at school in a more fun way. The limited trial application uses the System Usability Scale (SUS) as a benchmark for the perception of system usability, with a result of 85,3 which means it has a grade B grade with an Adjective Rating Excellent.
\end{abstract}

Keywords: gamification; children with special needs; learning media.

Diterima: 30 Juni 2020

Disetujui: 9 Desember 2020

Dipublikasi: 21 Desember 2020
(C2020 Tri Sagirani, Nunuk Wahyuningtyas, Sri H.E. Wulandari, Wawan W. Efendi Under the license CC BY-SA 4.0 


\section{Pendahuluan}

Corona Virus Disease 2019 (COVID-19) merupakan corona virus jenis baru (SARS-CoV-2 yang telah diketahui bersama telah mengejutkan dunia, diawali dengan kejadian di Kota Wuhan-Tiongkok dan saat ini telah menyebar diseluruh belahan dunia menjadi pandemi, termasuk di Indonesia. Kemunculannya memberikan dampak yang luar biasa diberbagai bidang, mulai dari kesehatan, ekonomi, budaya, ideologi, hukum, pertahanan keamanan dan tidak terkecuali berdampak pula pada bidang pendidikan.

Pada bidang pendidikan, pemerintah mengambil keputusan untuk memindahkan proses pembelajaran dari sekolah/ madrasah menjadi di rumah, hal ini menghadirkan ketidaknyamanan di banyak pihak karena ketidaksiapan yang pada akhirnya menjadi faktor utama kebingungan dan kekacauan. Peralihan cara pembelajaran ini memaksa berbagai pihak untuk memanfaatkan teknologi sebagai media pembelajaran daring, namun dalam pelaksanaannya terdapat beberapa faktor yang turut menghambat efektivitas jalannya pembelajaran. Faktor tersebut antara lain kurangnya penguasaan teknologi, keterbatasan sarana dan prasarana, jaringan internet dan juga biaya. Rendahnya literasi teknologi di tengah masyakat juga mendukung kondisi yang tidak menguntungkan. Pembelajaran menjadi sangat membosankan bagi anak dan merepotkan bagi orang tua.

Kerumitan yang terjadi tidak hanya untuk sekolah/madarasah dan anak-anak pada umumnya, namun juga terjadi pada anak berkebutuhan khusus (ABK). Belajar dari rumah akibat pandemi Covid-19 menghadirkan dinamika yang berbeda dan menarik untuk disimak khususnya bagi $A B K$ dan orang tua yang mendampingi. Menurut UNICEF ada beberapa hal yang harus diperhatikan untuk menjamin jalannya pembelajaran dirumah menjadi lancar, optimal dan berkualitas, antara lain pentingnya memberikan pemahaman kepada anak tentang kondisi saat ini, pentingnya orang tua untuk tetap bersikap positif menghadapi kondisi yang ada, pentingnya membuat jadwal belajar dan orang tua perlu mengatasi perilaku anak yang cenderung muncul dalam proses belajar di rumah. Dalam perjalanan belajar dirumah orang tua mulai kesulitan untuk mengatur jadwal belajar anak. Materi belajar yang terbataspun membuat anak jadi cepat merasa bosan menjalankan aktifitasnya. Dari waktu ke waktu anak semakin merasa bahwa belajar di rumah menjadi hal yang sangat tidak menyenangkan.

Penelitian ini mengambil bagian untuk memberikan alat bantu bagi orang tua dalam memudahkan menyusun jadwal belajar harian bagi ABK. Aplikasi ini pula menyediakan materi belajar yang beragam yang dapat dimanfatkan oleh orang tua untuk memandu dan mendampingi anak belajar di rumah dengan terarah dan lebih menarik. Bagi ABK aplikasi ini membuat aktifitas belajar, bermain dan menjalankan 
rutinitasnya menjadi lebih menarik. Aplikasi dibangun dengan berbasis android dengan pendekatan gamification. Gamification adalah sebuah proses game yang dapat meningkatkan motivasi kinerja melalui peningkatan keterlibatan pengguna dengan rasa antusias dalam menjalankan tantangan yang ada. Hasil dari proses ini dapat berupa pengalaman pengguna dan hasil dari keterlibatan pengguna yang berbentuk nilai tertentu atau capaian lain selama proses (Huotari dan Hamari, 2012). Dalam aktifitas keseharian gamification juga disebut sebagai sebuah proses yang dapat mengubah konteks non games menjadi lebih menarik dengan mengintegrasikan game thingking, yaitu dengan mendesain sebuah aktifitas menyerupai games dan menghadirkan rasa menyenangkan (Deterding, Dixon, Khaled dan Nacke, 2011). Harapannya aplikasi ini dapat dimanfaatkan oleh orang tua dan anak untuk bersinergi menjalankan aktifitas harian di rumah baik untuk mengatur jadwal anak, menentukan tugas harian, belajar dan bermain dengan penuh semangat dan lebih menyenangkan.

\section{Metode}

Metode penelitian atau tahapan yang digunakan untuk menyelesaikan masalah penelitian ini adalah metode penelitian pengembangan, di mana peneliti melakukan pengembangan dengan rancang bangun aplikasi. Model pengembangan yang dipilih adalah The Work System Life Cycle Model (WSLC) (Alter, 2008). Alasan penggunaan model WSLC dalam pengembangan ini karena model ini mengekspresikan pandangan dinamis tentang bagaimana sistem kerja dengan kondisi perubahan yang sering terjadi seiring waktu melalui beberapa iterasi baik pada aktifitas yang direncanakan maupun yang tidak direncanakan. Terdapat empat tahapan yang dilalui yaitu: Operation and Maintenance, Initiation, Development, dan Implementation.

\section{a. Operation and Maintenance}

Pada tahap pertama ini yaitu tahap operasi dan pemeliharaan, peneliti melakukan pengamatan baik terhadap karakteristisk $A B K$, kebutuhan terhadap pembelajaran dirumah, kemampuan ABK dalam memanfaatkan teknologi informasi dan teknologi yang tepat untuk $A B K$ dan teknologi yang pernah ada dan digunakan oleh ABK. Analisis konsep dan tugas yang akan dilakukan oleh anak dan orangtua juga menentukan tujuan pembelajaran. Tahap ini menggabungkan adaptasi jangka pendek dan solusi proses untuk jangka panjang. Perubahan dalam praktik di lapangan ataupun pada tujuan yang terjadi saat melakukan adaptasi dan penyelesaian masalah menjadi hal yang biasa dan menjadi sebuah aktifitas rutin dalam mengembangkan aplikasi. 


\section{b. Initiation}

Tahap ini peneliti menuangkan ide yang menghadirkan solusi yang mungkin tidak terduga. Menemukan tujuan baru yang pada awalnya tidak diantisipasi. Peneliti menuangkan setiap tujuan yang ingin dicapai dalam sebuah rancangan aplikasi yang akan digunakan, meliputi penyusunan standard hasil, pemilihan media sesuai dengan karakteristik anak dan tujuan yang akan dicapai, menentukan format dan membuat rancangan awal. Pada tahap ini disampaikan bahwa pengguna aplikasi yang telah diidentifikasi dan dikelompokkan dalam dua kelompok, yaitu : Orang tua dan Anak berkebutuhkan khusus.

Tahap kedua ini juga dilakukan pemilihan teknologi yang akan digunakan, dalam hal ini peneliti akan membangun aplikasi berbasis android yang dapat membantu orang tua dan anak dalam menjalankan aktifitas harian di rumah. Tahap ini diawali dengan menyusun alur aktifitas dari orang tua dan anak sebagai standar hasil dan tujuan dalam membangun aplikasi.

Pada tahap ini pula dilakukan pemilihan media dan menentukan format adalah hal penting yang menjadi perhatian. Dalam penelitian ini format konten gamification berisi elemen permainan, mekanisme permainan, dan berfikir seperti permainan yaitu mengubah konten agar berjalan layaknya sebuah proses permainan (Kapp dan Cone, 2020). Elemen yang paling umum untuk mengubah konten pembelajaran biasa menjadi konten yang berkonsep gamification (Clark dan Mayer (2011); Sitzmann (2011); Sagirani, Sunarto, Hariadi, Amelia dan Lemantara (2018)), yang digunakan adalah karakter, tantangan, interaktif, cerita, umpan balik dan kebebasan untuk gagal.

c. Development

Tahap pengembangan adalah tahap untuk menghasilkan produk pengembangan yang berupa aplikasi berbasis android dengan menggunakan pendekatan gamification. Elemen dalam gamification yang digunakan adalah: Karakter dan tantangan, interaktif dan cerita, dan umpan balik dan kebebasan untuk gagal.

Hasil dari aplikasi diuji cobakan untuk memastikan apakah karya yang dihasilkan telah sesuai dengan kebutuhan penggunanya yaitu orang tua dan anak. Uji coba menggunakan kuesioner System Usability Scale (SUS) sebagai tolak ukur persepsi kegunaan system (Broode, 2013).

d. Implementation

Proses Implementasi merupakan suatu tahap akhir dalam membangun aplikasi. Tahap ini dilakukan untuk mempromosikan produk pengembangan agar bisa diterima pengguna, baik secara individu maupun kelompok. Dalam pelaksanaan diseminasi perlu dilakukan pelatihan untuk penggunaan aplikasi baik kepada orang tua maupun 
anak. Pada penelitian ini tahap diseminasi baru dilakukan secara terbatas pada responden, untuk mencoba dan memberikan penilaian terhadap aplikasi dengan hasil yang telah disampaikan pada tahap pengembangan.

Empat tahap yang dijelaskan dalam WSLC Model (Alter, 2008) akan berjalan dengan dinamis, perubahan bisa saja terjadi sewaktu-waktu, terus berkembang sesuai dengan kebutuhan jaman dan kebutuhan dari penggunanya.

\section{Hasil dan Pembahasan}

Hasil

Penelitian ini menghasilkan sebuah aplikasi berbasis android yang dapat dimanfaatkan oleh orang tua dan anak untuk membantu proses belajar di rumah dengan lebih menyenangkan. Kerangka model dalam pemanfaatan aplikasi dalam pembelajaran ini akan disampaikan dalam 2 model untuk kelompok pengguna yang berbeda yaitu orang tua dan anak. Kelompok pengguna pertama dari aplikasi adalah orang tua, kerangka model pada gambar 1 dapat berkembang terus sesuai dengan perkembangan dan kemampuan dari pengguna. Gambar 1 adalah model proses pemanfaatan aplikasi oleh orang tua.

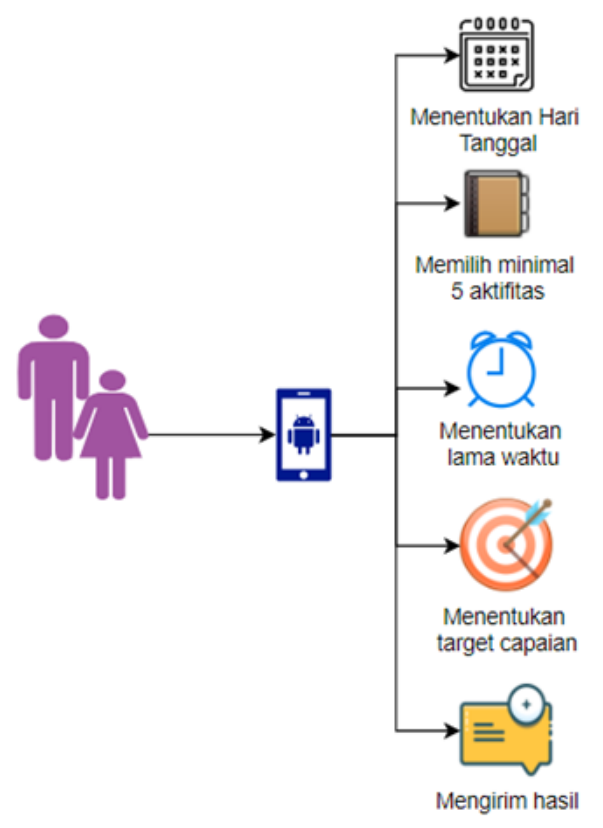

Gambar 1. Kerangka model kelompok pengguna orang tua

Pada Gambar 1 disebutkan orang tua memanfaatkan aplikasi berbasis android ini menggunakan smartphone. Terdapat lima menu utama didalamnya yaitu:

1. Menentukan hari dan tanggal untuk aktifitas anak

2. Memilih anak minimal lima aktifitas untuk hari tersebut 
3. Menentukan lama waktu untuk tiap aktifitas sesuai dengan kemampuan masing-masing anak

4. Menentukan target capaian

5. Mengirimkan hasil aktifitas anak kepada guru melalui whats app ataupun email

Pada Gambar 2 berikutnya disampaikan kerangka model untuk proses pemanfaatan aplikasi oleh anak. Model proses anak yang digunakan pada tahap pengembangan aplikasi berbasis android disusun dengan pendekatan gamification, yaitu sebuah konsep proses/ cara berfikir dan mekanika game yang melibatkan pengguna untuk menyelesaikan suatu masalah dan mempengaruhi perilaku pengguna (Zichermann dan Cunningham, 2011) yang dalam pengembangannya terdapat karakteristik dasar atau unsur yang terdapat dalam games pada umumnya yaitu aktivitas yang berfokus pada tujuan, mekanisme penghargaan, dan pelacakan kemajuan (Dickey, 2020).

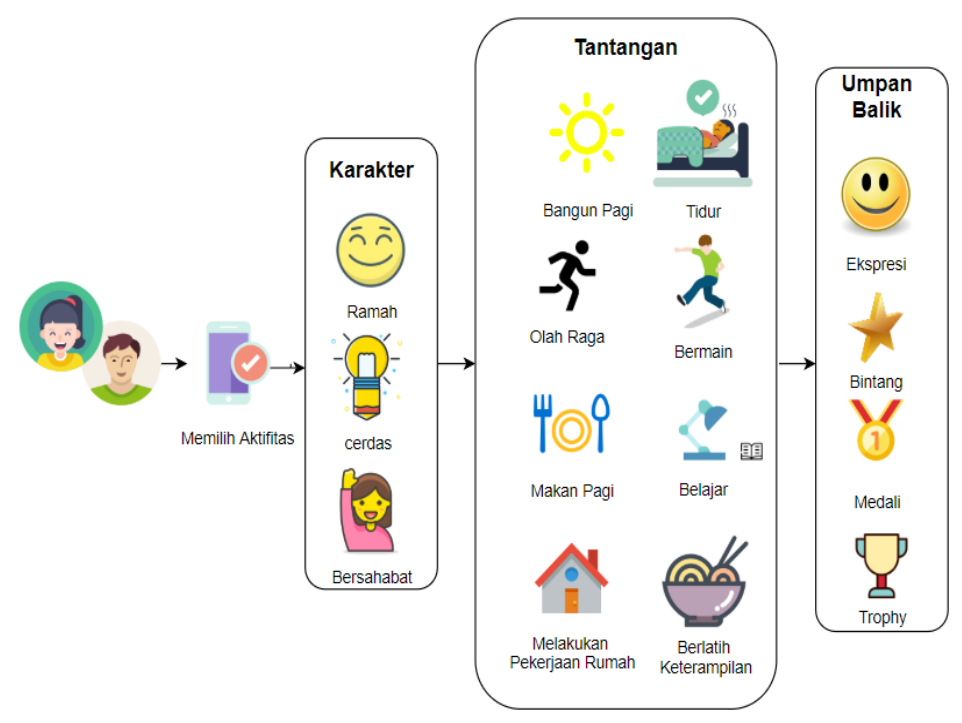

Gambar 2. Kerangka model kelompok pengguna anak

\section{Pembahasan}

Gamification, sebagai proses yang menciptakan pengalaman pembelajaran partisipatif, sangat cocok untuk pembelajaran aktif (Herrington dan Glover, 2013), gamification tidak hanya membuat suatu aktifitas menjadi lebih menyenangkan (Deese, 2020) namun penerapan gamification mampu memberikan manfaat meningkatkan perkembangan aspek kognitif dan juga meningkatkan peran aktif seseorang. Gamification juga memberikan motivasi, penghargaan atas capaian tertentu kepada peserta didik setelah berhasil memecahkan suatu permasalahan (Aribowo, 2014). Gamification dapat dilakukan untuk tujuan positif dalam proses pembelajaran. 
Berikut ini disampaikan beberapa gambaran dari aplikasi yang dibangun dengan menerapkan pendekatan gamification, antara lain pada elemen karakter tantangan interaktivitas cerita, umpan balik dan kebebasan untuk gagal.

\section{a. Elemen Karakter dan Tantangan}

Setiap pengguna dalam hal ini $A B K$, diberikan pilihan karakter (avatar) untuk mendeskripsikan diri. Foto profile untuk setiap anak dilengkapi dengan karakter positif yang menggambarkan dirinya. Pilihan karakter pada Gambar 3 (a) ini diharapkan dapat meningkatkan percaya diri setiap ABK. Setiap ABK juga mendapatkan minimal 5 aktifitas harian yang dipilihkan oleh orang tua sebagai cerminan elemen tantangan yang dapat dilihat pada Tambar 3 (b). Kelompok dalam aktifitas bagi anak meliputi bangun tidur, olah raga, belajar, bermain, kegiatan makan, aktifitas membantu menyelesaikan pekerjaan di rumah, dan melatih diri dalam usaha meningkatkan kemampuan keterampilan diri, hingga pengaturan jam istirahat/ tidur.

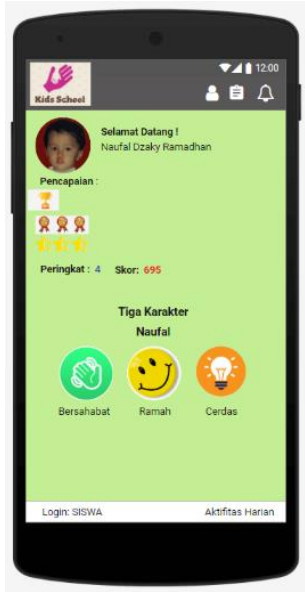

(a) Karakter

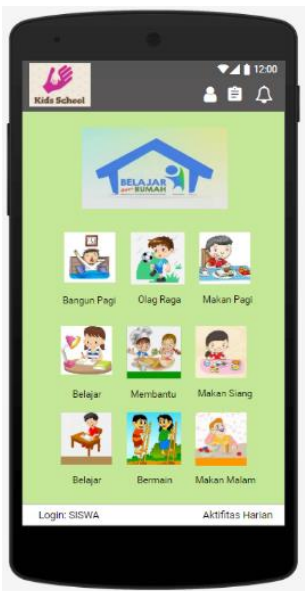

(b) Tantangan

Gambar 3. Pemanfaatan elemen karakter dan tantangan

\section{b. Elemen Interaktif dan Cerita.}

Setiap aktifitaspun akan memiliki pilihan beragam, misalnya aktifitas belajar, aplikasi akan memberikan pilihan belajar untuk anak, diantaranya membaca, berhitung, mewarnai dan aktifitas lain layaknya belajar dikelas dengan menggunakan buku. Terdapat elemen interaktif didalam menggunakan aplikasi, baik mendukung interaksi antara anak dengan aplikasi, juga antara anak dengan orang tua dalam pemakaian bersama media pembelajaran ini. Aplikasi inipun menampilkan elemen interaktif pada Gambar 4 (a), elemen ini dibangun dengan keterlibatan pengguna secara langsung. Salah satu wujud yang disampaikan dalam aplikasi ini diharapkan mampu memberi kesempatan kolaborasi antara orang tua dan $\mathrm{ABK}$ dalam proses belajar. Ketuntasan dalam setiap aktifitas ditunjukkan dengan warna yang berbeda dalam aplikasi, demikian juga penerapan penilaian berupa poin untuk setiap 
penyelesaian sebuah tantangan. Warna hijau menunjukkan aktifitas yang tuntas dan warna merah adalah aktifitas yang belum dilalui. Orang tua akan membantu dengan melakukan kontrol pada aktifitas anak, dengan memilihkan aktifitas harian yang tepat untuk anak setiap harinya. Elemen cerita terdapat bagian menu belajar, dipersiapkan alur cerita pada setiap konten/ materi yang akan dilalui oleh ABK. Cerita disampaikan dalam bentuk narasi ataupun audio/video sesuai jenis file materi yang akan digunakan. Berikut disampaikan contoh tampilan aplikasi untuk anak pada aktifitas belajar dan melatih diri dalam usaha meningkatkan kemampuan keterampilan. Pada contoh Gambar 4 (b), anak diminta untuk melihat dan mendengarkan dengan seksama video yang ditampilkan. Setelahnya anak diminta untuk mengurutkan cara membuat tepung. Orang tua akan mempersiapkan segala sesuatu yang dibutuhkan untuk membantu anak menyelesaikan tantangan untuk mengasah keterampilan. Tahapan selanjutnya adalah kolaborasi orang tua dan anak melakukan aktifitas bersama untuk melatih keterampilan membuat tepung dari bahan kulit pisang sesuai dengan langkah kerja yang sudah dipelajari.

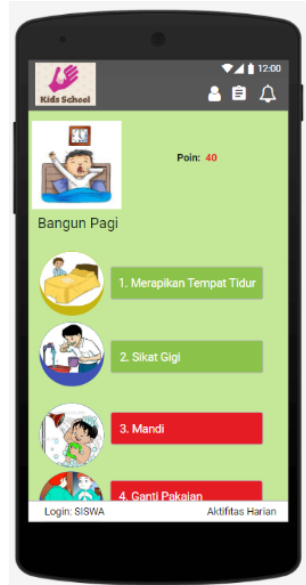

(a) Interaktif

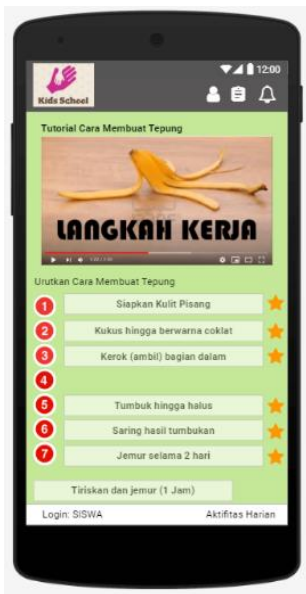

(b) Cerita

Gambar 4. Pemanfaatan elemen interaktif dan cerita

\section{c. Elemen Umpan Balik dan Kebebasan untuk gagal.}

Aplikasi ini memberikan umpan balik kepada ABK dengan menggunakan sistem poin, bintang, medali dan trofi. Setiap anak menyelesaikan tantangan atau tugasnya aplikasi akan memberikan umpan balik berupa komentar yang membangun. Tersedia banyak kata-kata umpan balik yang positif dan memotivasi anak yang akan ditampilkan secara acak untuk setiap keberhasilan anak seperti pada Gambar 5 (a). 


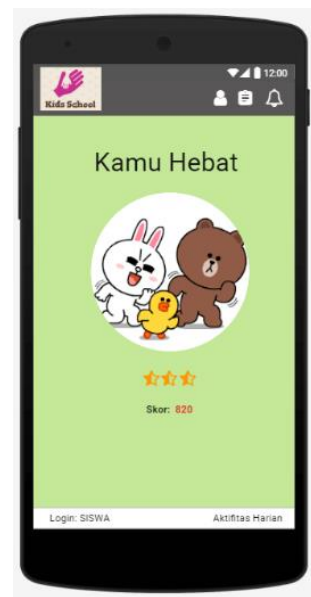

(a) Umpan balik

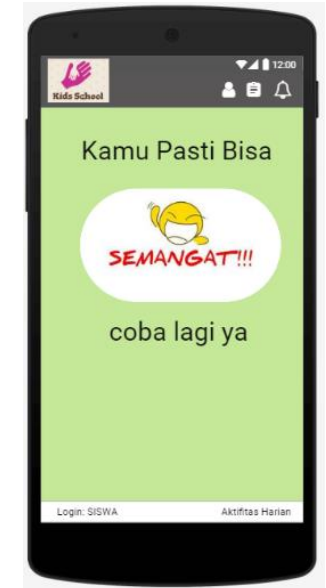

(b) Kebebasan untuk gagal

Gambar 5. Pemanfaatan elemen umpan balik dan kebebasan untuk gagal

Sistem juga memperkenankan kegagalan seorang anak dengan tetap memberikan umpan balik positif yang membangun, dengan maksud untuk anak kembali mencoba menyelesaikan tugas yang sudah diberikan. Sistem memberikan kesempatan berulang kali kepada anak yang melakukan kegagalan hingga dia menemukan penyelesaian yang tepat secara mandiri atau dengan bantuan orang tua.

Pada bagian akhir dari tahap pengembangan ini, aplikasi yang dihasilkan selanjutnya diuji coba dengan pendekatan persepsi kegunaan. Uji coba persepsi kegunaan dilakukan pada tahap implementasi terbatas terkait User Interface (UI) dan User Experience (UX) pada sistem. Dalam uji coba persepsi kegunaan ini penulis menggunakan kuesioner System Usability Scale (SUS) sebagai tolok ukur persepsi kegunaan sistem yang sejak digunakan 34 tahun yang lalu masih relevan dengan kondisi saat (Brooke, 2013). Dari hasil perhitungan skor SUS didapatkan rata-rata skor SUS sebesar 85,3, dengan rata-rata tersebut hasil uji coba menyatakan bahwa persepsi kegunaan sistem ini mendapatkan Grade Scale "B" dengan Adjective Rating "Excellent". Dapat disimpulkan bahwa penilaian terkait User Interface (UI) dan User Experience (UX) dari aplikasi dapat dikategorikan sistem User Friendly.

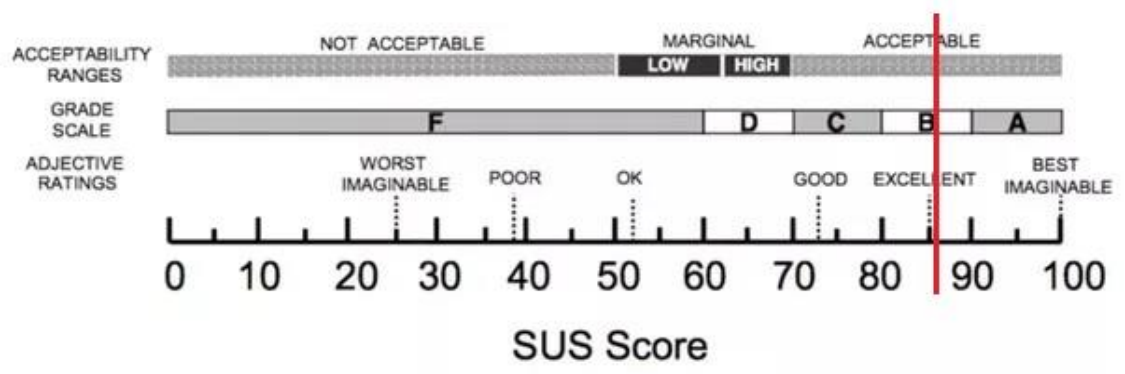

Gambar 6. Hasil pengukuran SUS 


\section{Kesimpulan}

Media pembelajaran dengan memanfatkan pendekatan gamification mampu menghadirkan kondisi belajar yang lebih menyenangkan. Hasil penelitian berupa aplikasi berbasis android ini menuntut orang tua dan anak berkolaborasi dalam melaksanakan pembelajaran dirumah. Aplikasi telah diuji coba menggunakan System Usability Scale mendapatkan nilai rata-rata 85.3 dari persepsi pengguna terhadap kegunaan sistem. Pengembangan kedepan aplikasi ini dapat ditambahkan dengan menambah kelompok pengguna dari guru atau pengelola sekolah, dengan harapan terjadi kolaborasi yang baik antara anak, orang tua dan sekolah.

\section{Ucapan Terimakasih}

Penelitian ini didukung oleh Bagian Penelitian dan Pengabdian Masyarakat Universitas Dinamika, dan Sekolah Luar Biasa C1 "Kumara I" sebagai mitra dalam Program Kemitraan Masyarakat.

\section{Daftar Pustaka}

Alter, S. (2008). Defining information systems as work systems: Implications for the IS field. European Journal of Information Systems, 17(5), 448-469.

Aribowo, E. K. (2014). Gamification: adaptasi game dalam dunia pendidikan. Prosiding Seminar Nasional Pendidikan ISPI Jawa Tengah. Surakarta, pp. 121-131.

Brooke, J. (2013). SUS: A Retrospective. Journal of Usability Studies, 8(2).

Clark, R.C. \& Mayer, R. (2011). E-learning and the science of instruction: proven guidelines for consumers and designers of multimedia learning. San Francisco: Pfeiffer.

Deese, A. (2020). Benefit of Gamification. https://ssee.si.edu, Retrieved May 2020.

Deterding, S., Dixon, D., Khaled, R. \& Nacke, L. (2011). From game design elements to gamefulness: defining gamification. Proceedings of the 15th International Academic MindTrek Conference: Envisioning Future Media Environments, MindTrek, pp. 9-15.

Dickey, M. D. (2005). Engaging by design: how engagement strategies in popular computer and video games can inform instructional design. Education Training Research and Development, 53(2), 67-83.

Herrington and Glover, I. (2013). Play as you learn: gamification as a technique for motivating learners. Proceedings of EdMedia: World Conference on Educational Media and Technology, pp. 1999-2008. 
Huotari, K. dan Hamari, J. (2012) Defining gamification: a service marketing perspective. Proceeding of the 16th international academic MindTrek, pp. 1722.

Kapp K. M. dan Coné, J. (2012). What every chief learning officer needs to know about games and gamification for learning, Institute for Interactive Technologies, (pp. 1-5)

Sagirani, T., Sunarto, M.J.D., Hariadi, B., Amelia, T., dan Lemantara, T. (2018). Prototype of Mobile Learning Application (MoLearn) by Utilizing the Gamification Concept. Proceedings of 6th International Conference on MOOCs, Innovation and Technology in Education (MITE), pp.1-5.

Sitzmann, T. (2011). A meta-analytic examination of the instructional effectiveness of computer-based simulation games. Personnel Psychology, 64(2), 489-528.

Zichermann, G. dan Cunningham, C. (2011). Gamification by design: implementing game mechanics in web and mobile apps. Sebastopol: O'Reilly Media. 